\title{
Penerapan Permainan Kecil dalam Proses Pembelajaran Penddikan Jasmani Olahraga dan Kesehatan
}

\author{
Hesti Yose ${ }^{1}$, M. Ridwan ${ }^{2}$ \\ ${ }^{123}$ Fakultas Ilmu Keolahragaan, Universitas Negeri Padang, Indonesia. \\ E-mail: hestiyos@gmail.com ${ }^{1}$, m.ridwan@,fik.unp.ac.id ${ }^{2}$
}

\begin{abstract}
Abstrak
Masalah yang di kemukakan dalam penelitian ini adalah bagaimana pelaksanaan permainan kecil dalam proses pembelajaran penjas orkes di MTsN MODEL gunung pangiun padang,sehubungan dengan masalah di atas maka penulisan bertujuan untuk melihat bagaimana penerapan permainan kecil dan proses pembelajaran Penjasorkes

Jenis Penelitian ini bertujuan untuk mendeskripsikan penerapan permainan kecil dalam proses pembelajaran Penjas Orkes di MTsN Model Gunung Pangilun Padang. Penelitian ini berbentuk deskriptif. Populasi penelitian ini adalah seluruh seluruh murid kelas VIII MTsN MODEL Padang yang berjumlah 501 orang, Teknik sampel yang digunakan adalah Random Sampling diambil 10\% berjumlah 50 orang. Alat pengumpulan data adalah kuesionoer menggunakan model skala Guttman dengan kategori Ya dan Tidak. Analisis data menggunakan teknik prosentase.

Hasil yang diperoleh dari penelitian menunjukkan penerapan permainan kecil dalam proses pembelajaran Penjas Orkes di Gunung Pangilun dalam kategori baik. Hal ini dibuktikan dengan penilaian siswa diperoleh sebanyak 43 orang $(86 \%)$ responden menyatakan Ya, dan 7 orang $(14 \%)$ responden menyatakan Tidak. Dari hasil ini menunjukkan bahwa penerapan permainan kecil akan dapat meningkatkan motivasi siswa untuk mengikuti proses pembelajaran dan juga dapat meningkatkan intelektual siswa. Selain itu permainan kecil ini dapat disesuaikan dengan kondisi sarana dan prasarana yang ada. Dengan penerapan permainan kecil dalam proses pembelajaran penjas orkes diharapkan siswa lebih tertarik untuk mengikuti kegiatan pembelajaran ini.
\end{abstract}

Kata Kunci: Pembelajaran Permainan Kecil, Pendidikan Jasmani, Olahraga, Kesehatan

\begin{abstract}
The problem raised in this study is how the implementation of a small game in the learning process of the Physical Education Orchestra in MTSN Gunung Pangiun Padang MODEL, in connection with the above problem, the writing aims to see how the application of small games and the learning process of Penjasorkes.

This type of research aims to describe the application of small games in the learning process of Physical Education Orchestra in MTsN Model Mount Pangilun Padang. This research is in the form of descriptive. The population of this study were all students of class VIII MTSN MODEL Padang, amounting to 501 people, the sample technique used was Random Sampling taken 10\% totaling 50 people. The data collection tool is a questionnaire using the Guttman scale model with the Yes and No categories. Data analysis using percentage techniques.

The results obtained from the study indicate the application of small games in the learning process of Physical Education Orchestra in Mount Pangilun in the good category. This is evidenced by the assessment of students obtained as many as 43 people (86\%) of respondents said yes, and 7
\end{abstract}




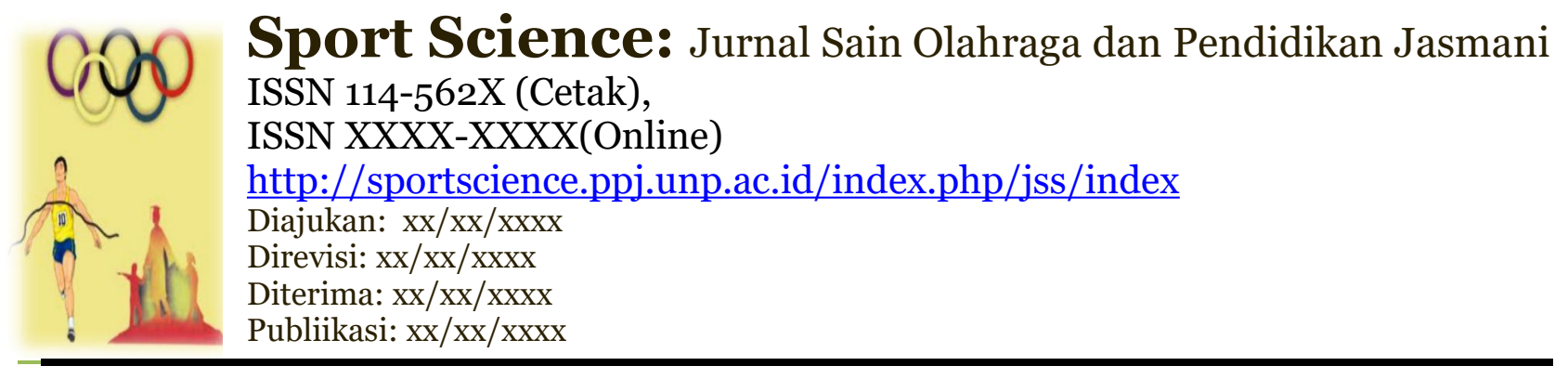

people (14\%) of respondents said no. From these results it shows that the application of small games will be able to increase students 'motivation to follow the learning process and can also improve students' intellectuals. Besides this little game can be adapted to the conditions of existing facilities and infrastructure. By implementing a small game in the learning process of the orchestra physical education, it is hoped that students will be more interested in participating in this learning activity.

Keywords: Learning Little Game, Physical Education, Sports, Health

\section{PENDAHULUAN}

Pendidikan jasmani dan kesehatan di sekolah memiliki penerapan yang penting yaitu memberikan kesempatan kepada siswa untuk terlibat langsung dalam berbagai pengalaman belajar melalui aktivitas jasmani dan kesehatan yang dilakukan secara sistematis pembekalan kegiatan pembelajaran disekolah diarahkan untuk membina pertumbuhan dan perkembangan fisik. Selama ini telah terjadi kecendrungan dalam memberikan makna mutu pendidikan yang hanya dikaitkan dengan aspek kemampuan kognitif.

Asnaldi (2015) "Agar tercapainya ideal di atas, maka dalam melaksanakan pengajaran pendidikan jasmani dan kesehatan sebaiknya guru penjaskes harus mempertimbangkan kemampuannya. metoda. materi. akitivitas belajar. sarana dan prasarana serta motivasi siswa. Dengan mempertimbangkan unsur-unsur dan ideal tersebut diharapkan proses pengajaran pendidikan .jasmani dan kesehatan dapat berjalan dengan baik sesuai dengan tujuan".

Sebab tanpa adanya tujuan dan pandangan kepada aspek-aspek yang lain seperti moral, akhlak, budi pekerti, seni, psikomotor, afektif, serta life skill pendidikan belum dikatakan bermutu, pendidikan jasmani olahraga dan kesehatan merupakan media untuk mendorong meningkatkan kesegaran jasmani, motivasi, pertumbuhan dan perkembangan fisik, perkembangan intelektual, prestasi belajar, kondisi fisik, perkembangan psikis, keterampilan motorik, pengetahuan dan penalaran, penghayatan nilai-nilai (sikap, mental, emosional, sportivitas, spiritual, sosial) serta pembahasan pola hidup sehat yang bermuara untuk merangsang pertumbuhan dan perkembangan fisik dan psikis yang seimbang.

Berdasarkan pengamatan yang penulis lakukan disekolah, pemberian pendidikan jasmani disekolah dengan permainan kecil terlihat sangat tinggi minat siswa untuk melakukan serta mengikuti proses pembelajaran pendidikan jasmani olahraga dan kesehatan, karena mulai dari pelaksanaan, pemanasan sampai ke inti pokok materi ajar dilaksanakan dalam bentuk permainan dan perlombaan yang membuat para siswa gembira dan senang mengikuti, melaksanakan penjas orkes disekolah.

Perlu diketahui lagi bahwa permainan kecil merupakan salah satu aktivitas fisik yang dapat menunjang pelaksanaan pembelajaran penjas orkes disekolah, bahkan hal ini bisa dikatakan sesuatu yang sangat penting dalam proses pembelajaran penjas orkes disekolah. Pembelajaran sebenarnya menitik beratkan pada bagaimana proses mengajar terjadi.

Hal ini mementingkan proses belajar anak didik, bukan mementingkan guru yang mengajar. Sebab tidak ada artinya jika kepintaran atau kepiawaian seorang guru dalam mengajar kalau muridnya tidak merasa belajar. Jadi, yang paling utama adalah bagaimana peserta didik itu belajar, bukan bagaimana cara guru mengajar, walaupun cara mengajar seorang guru merupakan hal yang terpenting. Biasanya istilah Proses Belajar Mengajar seperti tidak dapat dipisahkan, artinya kalau ada yang belajar pasti ada yang mengajar.

Sarana dan prasarana merupakan pendukung segala hukum dan prinsip serta azaz-azaz yang berlaku dalam pengajaran. Pada umumnya tetap berlaku dalam pengajaran olahraga atau penjas. Akan tetapi karena pengajaran olahraga atau penjas berlangsung dilapangan dan di gedung olahraga, maka kegiatan pembelajarannya mempunyai karakteristik tersendiri yang menjadikan dia berbeda dengan pengajaran di lokal. 
Agar pembelajaran penjas orkes supaya lebih menarik salah satunya adalah yang mengajar penjas orkes harus secara langsung erjun ke lapangan untuk ikut dan memperhatikan gerakan-gerakan yang sedang dilakukan siswa. Sehingga pelajaran penjas orkes ini betul-betul diminati siswa-siswi dan menjadi bagian dari diri mereka sendiri. Guru pendidikan jasmani yang propesional sebelum melaksanakan tugasnya dilapangan hendaknya terlebih dahulu merencanakan dan mempersiabkan permainan - permainan yang meransang siswa agar perhatiannya terpusat kepada kegiata yang dilakukan meskipun alat tidak lengkap, alat yang tidak sesui untuk anak, kemampuan anak, kemampuan anak terbatas, maka dengan permainan kecil guru penjasorkes bisa menyesuaikan dengan keadaan.

Menurut gusril $(2008 ; 16)$ bahwa salah satu upaya meningkatkan guru pendidikan jasmani di sekolah dituntut senantiasa aktif dalam melakukan pelaksanan pengajaran yang harus disesuaikan dengan karakteristik anak seperti yang disampaikan oleh slamento $(1987 ; 99)$ dalam proses PBM guru mempunyai tugas untuk mendorong, membimbing, memberi fasilitas belajar bagi murid-muridnya untuk mencapai tujuan.

Pada dasarnya sarana dan prasarana dalam pembelajaran pendidikan jasmani sangat memegang peranan penting. Hal itu harus disesuaikan dengan kebutuhan demi kelancaran pendidikan jasmani. Sarana yaitu semua alat olahraga yang dapat dipindahkan seperti bola, net dan sebagainya. Sedangkan prasarana adalah fasilitas olahraga yang tidak dapat dipindahkan seperti lapangan gedung olahraga dan sebagainya.

Segala bentuk sarana dan prasarana di atas sangat berpengaruh terhadap proses belajar pendidikan jasmani disekolah atau madrasah, apabila terabaikan maka otomatis proses belajar mengajar tidak terlaksana secara semestinya. Untuk itu diperlukan kreatif guru untuk mencoba, mengkreasikan, memodifikasi serta merencanakan serta merencanakan sumber-sumber yang ada dan biasa dijadikan penunjang terlaksananya proses belajar mengajar.

Permainan kecil merupakan aktifitas fisik, disamping untuk pemanasan juga dapat untuk membantu materi inti yang akan dilaksanakan pada waktu itu. Lagi pula permainan kecil tidak memerlukan peralatan yang begitu sulit. Begitu pula permainan kecil tidak menuntut secara khusus dalam segi waktu, peserta, maupun alat yang digunakan. Guru Penjas tidank sulit untuk mencarikan macam-macam permainan kecil, yang dapat diarahkan dan disesuaikan dengan materi yang akan diberikan. Permainan kecil baik untuk pemanasan, latihan inti, penenangan

Melalui mempelajari perkembangan individu ini manusia beserta sejarah hidupnya, dapat diungkapkan bahwa permainan itu telah ada di dunia semenjak manusia itu ada. Oleh karena itu manusia tumbuh tidak dapat mengelakkan dan menjauhkan alam permainan. Begitu pula anak-anak sedang berkembang melewati bermacam-macam permainan sebagai kodrat yang alami membantu mereka.

Perlaksanaan permainan siswa dibagi dua kelompok, masing masing kelompok ada yang mewakili untuk swit mencari mana yang menang atau yang memegang bola cara permainan. Kelompok yang menang memulai dengan melempar susunan batu sampai roboh, kalau sudah roboh kelompok penjaga bersiaga di tempat batu yang roboh dan melempari kelompok yang merobohkan bola tadi, begitu pula kelompok yang merobohkan batu berusaha menyusun batu kembali, sampai ada kelompok yang menang yang bisa meyusun batu dengan tidak ada angota kelompok yang kena pukulan bola. Kelompok yang menang boleh memberi hukuman pada yang kalah.

Keberhasilan dalam proses pembelajaran Penjas orkes dipengaruhi oleh berbagai faktor baik dari siswa itu sendiri maupun dari luar diri siswa tersebut. Salah satu faktor yang berasal dari dalam diri siswa tersebut adalah kebiasaan belajar, kebiasaan siswa sangat menentukan terhadap pencapaian hasil belajar siswa dalam proses belajar mengajar siswa memperoleh informasi yang baru, untuk mengikuti proses belajar, siswa dituntut untuk menerima materi dengan biak dan dapat menguasai dengan baik pula. Faktor dari luar siswa yaitu yang cukup dominan adalah faktor permainan kecil sebagai kegiatan fisik yang sangat mendukung dalam proses pembelajaran. 


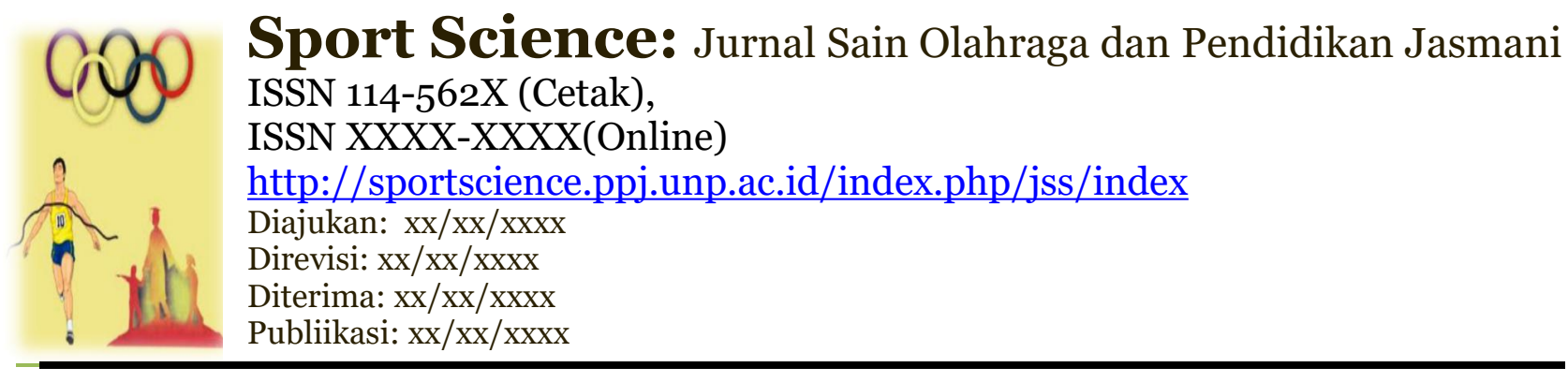

\section{METODE}

Berdasarkan permasalahan yang akan di bahas, dalam penelitian maka penelitian ini bersifat deskriptif yang bertujuan untuk melihat meninjau, mengetahui dan mengungkapkan keadaan apa adanya pada waktu penelitian dilakukan, kemudian hasil yang diolah dalam bentuk angka, jadi metode ini bertujuan memecahkan masalah yang ada pada penerapan permainan kecil dalam proses pembelajaran penjas orkes disekolah MTsN MODEL Padang, dan memberikan gambaran secara umum diikuti dengan mengklasifikasikan serta analisis data. Tempat penelitian ini dilaksanakan di MTsN MODEL Pangilun Padang, dengan waktu pelaksanaan Januari s/d April 2016.

Populasi dalam penelitian ini adalah seluruh siswa kelasVII, VIII, dan IX MTsN MODEL Padang, untuk lebih jelasnya mengenai populasi table penelitian dapat dilihat pada tabel di bawah ini.kelas VIII. Jumlah siswa-siswi kelas VIII MTs N MODEL Padang sebagai populasi 501 siswa dari 12 kelas.Teknik yang Dalam menentukan sample yang perlu diperhatikan yaitu kebebasan yang sama untuk terpilih sebagai sampel. Maka yang menjadi sampel dalam penelitian ini adalah $10 \%$ dari jumlah populasi yang ada. Arikunto (2006:104), sehingga sampel 10\% dari 501 populasi berjumlah 50 orang dengan menggunakan teknik Random Sampling ialah cara mengambilan sampel dari anggota populasi dengan menggunakan acak tanpa memperhatikan strata atau tingkatan dalam anggota populasi. Jumlah siswa-siswi kelas VIII MTs N MODEL Padang sebagai sampel 50 siswa dari 12 kelas.

Untuk mengumpulkan data penelitian digunakan teknik angket, wawancara, observasi di lapangan. Sedangkan alat yang digunakan untuk mengumpulkan data adalah kuesioner tapi dalam penyebarannya penelitian akan mendampingi sumber data dalam mengisi kuesioner, kuesioner tersebut akan disusun berdasarkan variable penerapan permainan kecil.

1. Pengumpulan data dengan angket yaitu suatu cara pengumpulan data dengan menyusun daftar pertanyaan yang diberikan kepada orang lain untuk beredia memberikan respon(responden) sesuai dengan perintah.

2. Sedangkan data dengan observasi yaitu melakukan pengamatan secara langsung ke objek penelitian untuk melihat dari dekat kegiatan yang dilakukan tentang peristiwa atau sesuatu yang dianggap penting dicatat dengan singkat tanpa harus menuruti aturan tertentu.

\section{Intrumen penelitian}

Alat yang di perlukan dalam pengumpulan data dalam penelitian ini adalah melalui angket (kuesioner) langkah-langkah yang diperlukan dalam pembuatan angket ini adalah:

1. Menentukan indikator sesuai yang variabel yang dijadikan pedoman dalam menentukan butir-butir instrument

2. Membuat kisi-kisi angket

Tabel 3. Kisi-kisi Instrumen

\begin{tabular}{|c|c|c|c|}
\hline No & Indikator & Sub Indikator & No Item \\
\hline 1. & Motivasi & $\begin{array}{ll}\text { - } & \text { intrinsik } \\
\text { - } & \text { ekstrinsik }\end{array}$ & $\begin{array}{l}1,2,3,17,30 \\
4,5,16\end{array}$ \\
\hline 2. & Intelektual & $\begin{array}{ll}\text { - } & \text { pemahaman } \\
\text { - } & \text { kemampuan }\end{array}$ & $\begin{array}{l}6,7,25 \\
8,9,22,23\end{array}$ \\
\hline 3. & Sarana dan Prasarana & $\begin{array}{ll}\text { - } & \text { sarana } \\
\text { - } & \text { prasarana }\end{array}$ & $\begin{array}{l}10,11 \\
12,29\end{array}$ \\
\hline 4. & Permainan kecil & $\begin{array}{ll}\text { - } & \text { peraturan } \\
\text { - } & \text { modifikasi }\end{array}$ & $\begin{array}{l}13,14,18,26 \\
15,24\end{array}$ \\
\hline 5. & Kemampuan guru & - permainan kecil & $19,20,21,27,28$ \\
\hline
\end{tabular}


3. Melihatkan instrumen pacarnya untuk melihat keayakan instrumen. Dalam pengumpulan data atau alat yang digunakan adalah kuesioner dengan model Skala Guttman yang disusun berpedoman pada kajian teori atau berdasarkan indikator-indikator yang ditetapkan guna menjawab pertanyaan penelitian. Penyusunan angket ini dilakukan dengan dua kategori yaitu Ya dan Tidak.

Data yang dikumpulkan dalam penelitian ini dianalisis dengan statistik deskriptif dan menggunakan tabulasi frekuensi atau analisa persentase. Untuk mencari persentase jawaban menggunakan rumus :

$$
\mathrm{P}=\frac{\mathrm{f}}{\mathrm{N}} \times 100 \%
$$

Keterangan:

$$
\begin{aligned}
\mathrm{P} & =\text { Persentase Jawaban } \\
\mathrm{F} & =\text { Frekuensi Jawaban } \\
\mathrm{N} & =\text { Jumlah Sampel } \\
& \text { (Sudjana, 1989: 129) }
\end{aligned}
$$

\section{HASIL DAN PEMBAHASAN \\ Hasil Penelitian}

Untuk mengetahui hasil penelitian tentang penerapan permainan kecil dalam proses pembelajaran Penjas Orkes di MTsN Model Gunung Pangilun dapat dilihat dari 5 (lima) indikator, yaitu: motivasi, intelektual, sarana dan prasarana, permainan kecil serta kemampuan guru. Untuk lebih jelasnya dapat diuraikan sebagai berikut.

\begin{tabular}{|c|c|c|c|c|c|c|}
\hline \multirow{3}{*}{$\begin{array}{l}\text { No. } \\
\text { Item }\end{array}$} & \multirow{3}{*}{ Pernyataan } & \multicolumn{4}{|c|}{ Jawaban Responden } & \multirow{3}{*}{$\mathbf{N}$} \\
\hline & & \multicolumn{2}{|l|}{ Ya } & \multicolumn{2}{|c|}{ Tidak } & \\
\hline & & $\mathbf{F}$ & $\%$ & f & $\%$ & \\
\hline 6. & $\begin{array}{l}\text { Pembelajaran penjas orkes melalui } \\
\text { permainan kecil dapat meningkatkan pola } \\
\text { pikir saya. }\end{array}$ & 47 & 94 & 3 & 6 & 50 \\
\hline 7. & $\begin{array}{l}\text { Pembelajaran penjas orkes dengan } \\
\text { permainan kecil mudah saya pahami dan } \\
\text { dimengerti. }\end{array}$ & 45 & 90 & 5 & 10 & 50 \\
\hline 8. & $\begin{array}{l}\text { Pembelajaran penjas orkes melalui } \\
\text { permainan kecil, saya dapat } \\
\text { mengembangkan kemampuan daya pikir } \\
\text { untuk menemukan hal yang baru. }\end{array}$ & 44 & 88 & 6 & 12 & 50 \\
\hline 9. & $\begin{array}{l}\text { Pembelajaran penjas orkes melalui } \\
\text { permainan kecil dapat mengembangkan } \\
\text { kemampuan keselamatan dan etika bagi } \\
\text { saya. }\end{array}$ & 44 & 88 & 6 & 12 & 50 \\
\hline 22. & $\begin{array}{l}\text { Pembelajaran penjas orkes melalui } \\
\text { permainan kecil dapat mengembangkan } \\
\text { pengetahuan memodifikasi permainan. }\end{array}$ & 45 & 90 & 5 & 10 & 50 \\
\hline
\end{tabular}

\section{Intelektual}

Data mengenai intelektual siswa diperoleh dari instrumen yang terdiri dari 7 (tujuh) butir pernyataan. Berdasarkan jawaban responden diperoleh hasilnya sebagai berikut.

Tabel 4. Distribusi Frekuensi Intelektual 


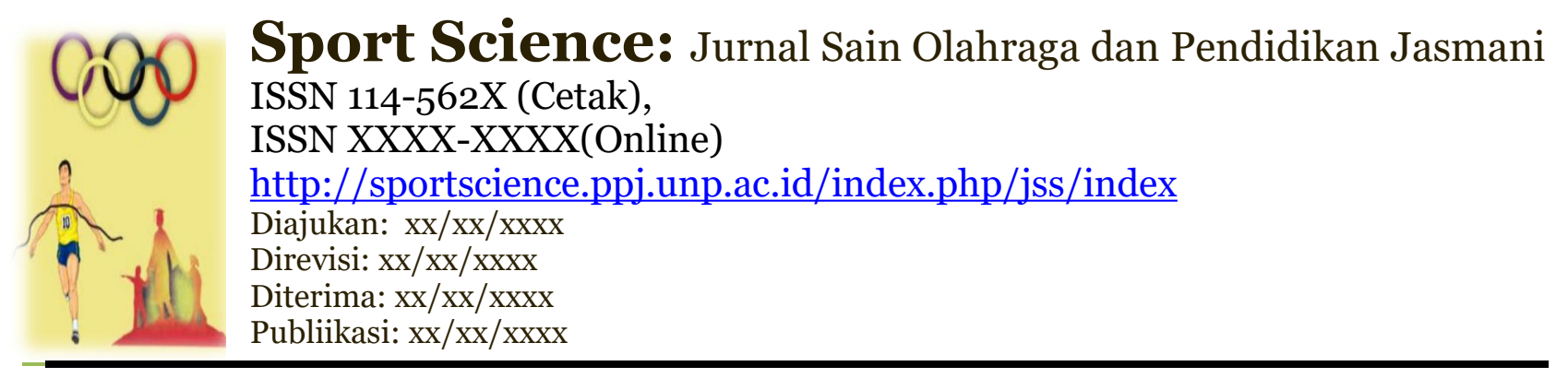

\begin{tabular}{|c|c|c|c|c|c|c|}
\hline 23. & $\begin{array}{l}\text { Pembelajaran penjas orkes melalui } \\
\text { permainan kecil dapat mengembangkan } \\
\text { kemampuan isyarat daya pikir bagi saya } \\
\text { untuk hal yang baru. }\end{array}$ & 45 & 90 & 5 & 10 & 50 \\
\hline 25. & $\begin{array}{lccr}\text { Pembelajaran penjas orkes } & \text { melalui } \\
\text { permainan kecil saya } & \text { dapat } \\
\text { membangkitkan berpikir kritis. } & \end{array}$ & 28 & 56 & 22 & 44 & 50 \\
\hline \multicolumn{2}{|c|}{ Rata-rata } & 43 & 86 & 7 & 14 & 50 \\
\hline
\end{tabular}

Tabel 4 diatas menunjukkan gambaran peningkatan intelektual siswa dari diterapkan permainan kecil dalam proses pembelajaran Penjas Orkes diperoleh 43 orang (86\%) responden menyatakan Ya dan 7 orang (14\%) responden menyatakan Tidak. Dari data ini dapat dikatakan bahwa pada umumnya siswa menyatakan bahwa permainan kecil yang diterapkan dalam proses pembelajaran Penjas Orkes akan dapat meningkatkan intelektual mereka.

\section{Sarana dan Prasarana}

Data mengenai sarana dan prasarana yang digunakan dalam penerapan permainan kecil pada proses pembelajaran Penjas Orkes diperoleh dari instrumen yang terdiri dari 4 (empat) butir pernyataan. Berdasarkan jawaban responden diperoleh hasilnya sebagai berikut.

Tabel 5. Distribusi Frekuensi Sarana dan Sarana

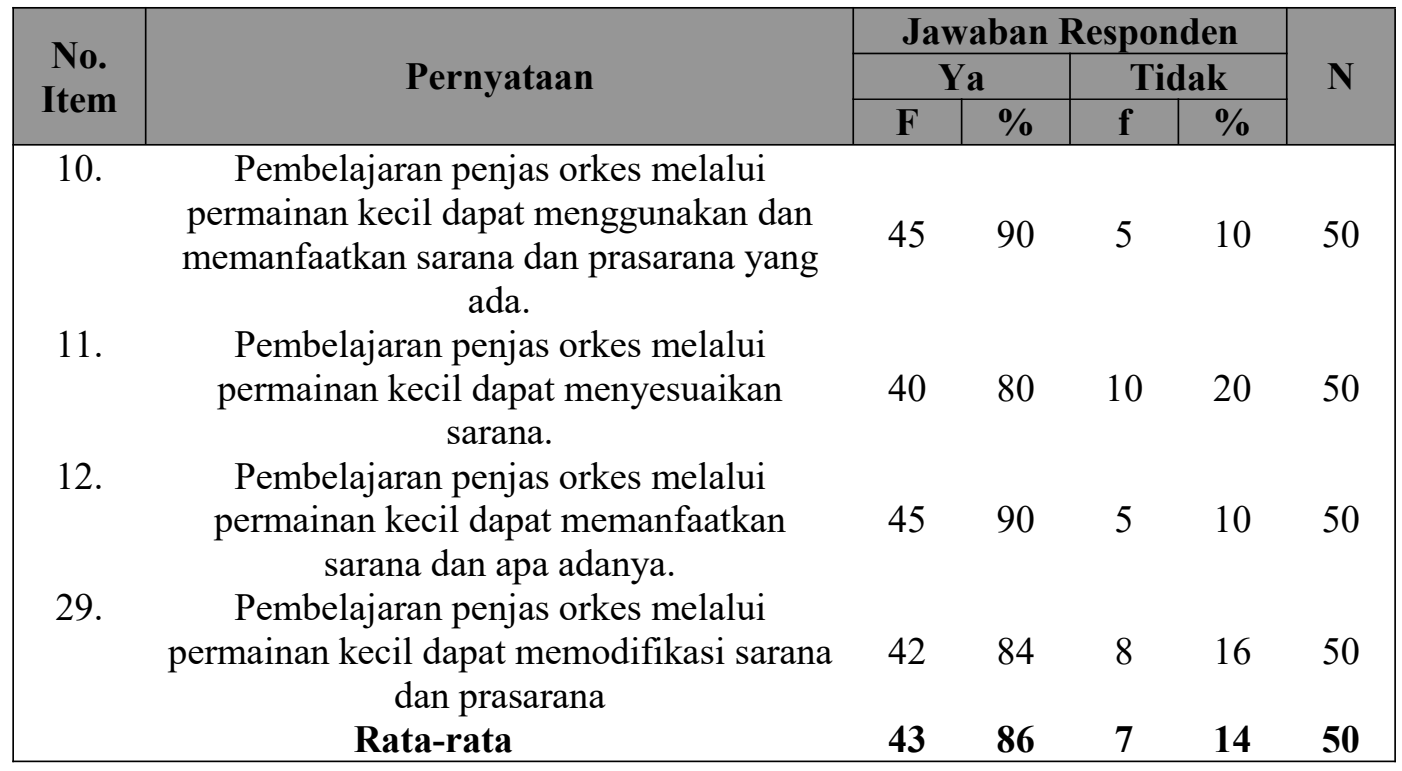

Tabel 5 diatas menunjukkan gambaran permainan kecil yang diterapkan dalam proses pembelajaran Penjas Orkes dapat dilaksanakan dengan menyesuaikan kondisi sarana dan prasarana yang ada di sekolah dinyatakan 43 orang $(86 \%)$ responden menyatakan Ya dan 7 orang (14\%) responden menyatakan Tidak. Dari data ini dapat dikatakan bahwa pada umumnya siswa menyatakan bahwa permainan kecil yang diterapkan dalam proses pembelajaran Penjas Orkes dapat dilaksanakan sesuai dengan kondisi sarana dan prasarana yang tersedia di sekolah.

\section{Permainan Kecil}

Data mengenai pelaksanaan permainan kecil pada pembelajaran Penjas Orkes diperoleh dari instrumen yang terdiri dari 6 (enam) butir pernyataan. Berdasarkan jawaban responden diperoleh hasilnya sebagai berikut. 
Tabel 6. Distribusi Frekuensi Permainan Kecil

\begin{tabular}{|c|c|c|c|c|c|c|}
\hline \multirow{3}{*}{$\begin{array}{l}\text { No. } \\
\text { Item }\end{array}$} & \multirow{3}{*}{ Pernyataan } & \multicolumn{4}{|c|}{ Jawaban Responden } & \multirow{3}{*}{$\mathbf{N}$} \\
\hline & & \multicolumn{2}{|c|}{ Ya } & \multicolumn{2}{|c|}{ Tidak } & \\
\hline & & $\bar{F}$ & $\%$ & $\mathbf{F}$ & $\%$ & \\
\hline 13. & $\begin{array}{l}\text { Pembelajaran penjas orkes melalui } \\
\text { permainan kecil dapat memodifikasi } \\
\text { peraturan yang ada. }\end{array}$ & 33 & 66 & 17 & 34 & 50 \\
\hline 14. & $\begin{array}{c}\text { Pembelajaran penjas orkes saya selalu } \\
\text { mengikutinya dengan peraturan yang } \\
\text { dibuat. }\end{array}$ & 45 & 90 & 5 & 10 & 50 \\
\hline 15. & $\begin{array}{l}\text { Pembelajaran penjas orkes melalui } \\
\text { permainan kecil dengan memodifikasinya } \\
\text { supaya tidak menemukan kendala. }\end{array}$ & 41 & 82 & 9 & 18 & 50 \\
\hline 18. & $\begin{array}{l}\text { Pembelajaran penjas orkes melalui } \\
\text { permainan kecil saya dan teman-teman } \\
\text { serius mengikutinya. }\end{array}$ & 31 & 62 & 19 & 38 & 50 \\
\hline 24. & $\begin{array}{l}\text { Pembelajaran penjas orkes melalui } \\
\text { permainan kecil mengembangkan } \\
\text { pengetahuan permainan. }\end{array}$ & 48 & 96 & 2 & 4 & 50 \\
\hline 26 & $\begin{array}{l}\text { Pembelajaran penjas orkes melalui } \\
\text { permainan kecil merupakan aktivitas fisik } \\
\text { yang menarik bagi saya. }\end{array}$ & 46 & 92 & 4 & 8 & 50 \\
\hline & Rata-rata & 41 & 82 & 9 & 18 & 50 \\
\hline
\end{tabular}

Tabel 6 diatas menunjukkan gambaran pelaksanaan permainan kecil dalam pembelajaran Penjas Orkes diperoleh 41 orang (82\%) responden menyatakan Ya bahwa pelaksanaan permainan kecil berjalan dengan baik, dan 7 orang $(14 \%)$ responden menyatakan Tidak. Dari data ini dapat dikatakan bahwa pada umumnya siswa menyatakan bahwa permainan kecil yang diterapkan dalam proses pembelajaran Penjas Orkes dapat dilaksanakan dengan baik.

\section{Kemampuan Guru}

Data mengenai kemampuan guru dalam melaksanakan permainan pada proses pembelajaran Penjas Orkes diperoleh dari instrumen yang terdiri dari 5 (lima) butir pernyataan. Berdasarkan jawaban responden diperoleh hasilnya sebagai berikut.

Tabel 7. Distribusi Frekuensi Kemampuan Guru

\begin{tabular}{|c|c|c|c|c|c|c|}
\hline \multirow{3}{*}{$\begin{array}{l}\text { No. } \\
\text { Item }\end{array}$} & \multirow{3}{*}{ Pernyataan } & \multicolumn{4}{|c|}{ Jawaban Responden } & \multirow{3}{*}{$\mathbf{N}$} \\
\hline & & \multicolumn{2}{|c|}{ Ya } & \multicolumn{2}{|c|}{ Tidak } & \\
\hline & & $\mathbf{F}$ & $\%$ & $\mathbf{F}$ & $\%$ & \\
\hline 19. & $\begin{array}{l}\text { Pembelajaran penjas orkes melalui } \\
\text { permainan kecil guru mampu menguasai } \\
\text { materi dengan baik. }\end{array}$ & 42 & 84 & 8 & 16 & 50 \\
\hline 20. & $\begin{array}{l}\text { Pembelajaran penjas orkes melalui } \\
\text { permainan kecil guru mampu membimbing } \\
\text { siswa melaksanakan proses pembelajaran. }\end{array}$ & 45 & 90 & 5 & 10 & 50 \\
\hline 21. & $\begin{array}{c}\text { Pembelajaran penjas orkes melalui } \\
\text { permainan kecil guru dapat memanfaatkan } \\
\text { sarana dan prasarana yang ada. }\end{array}$ & 46 & 92 & 4 & 8 & 50 \\
\hline 27. & Pembelajaran penjas orkes melalui & 43 & 86 & 7 & 14 & 50 \\
\hline
\end{tabular}




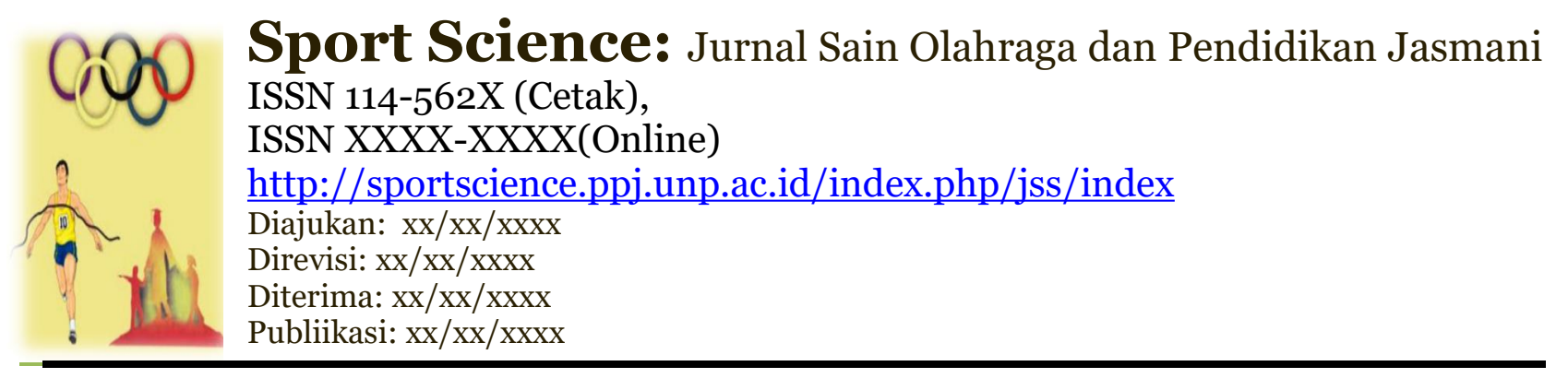

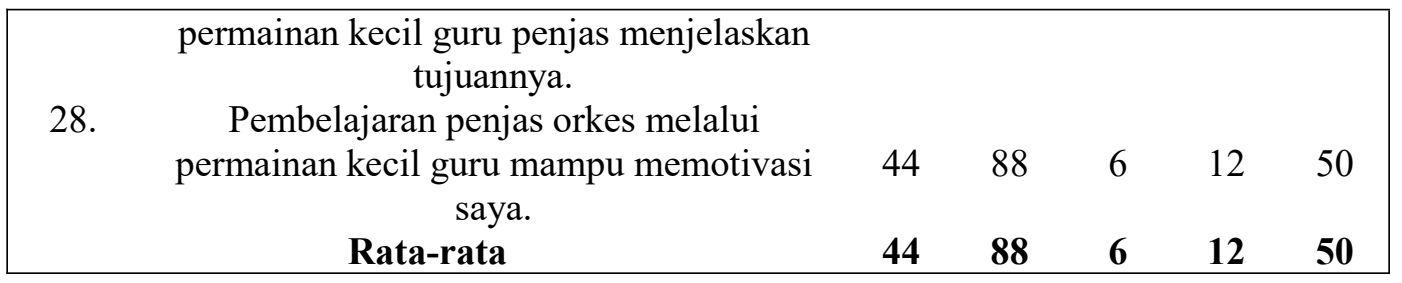

Tabel 7 diatas menunjukkan kemampuan guru dalam melaksanakan permainan kecil pada proses pembelajaran Penjas Orkes diperoleh 44 orang (88\%) responden menyatakan Ya bahwa guru mempunyai kemampuan yang baik dalam pelaksanaan permainan kecil, sedangkan 6 orang (12\%) responden menyatakan Tidak. Dari data ini dapat dikatakan bahwa pada umumnya siswa menyatakan bahwa guru mempunyai kemampuan yang baik dalam melaksanakan permainan kecil pada proses pembelajaran Penjas Orkes.

Selanjutnya, dari data-data yang diperoleh pada indikator penerapan permainan kecil dalam proses pembelajaran Penjas Orkes di atas, dirangkum rekapitulasi rata-ratanya untuk melihat gambaran secara keseluruhan mengenai penerapan permainan kecil pada proses pembelajaran Penjas Orkes yang dapat dilihat pada tabel berikut ini.

Tabel 8. Rekapitulasi Rata-rata Penerapan Permainan Kecil

\begin{tabular}{|l|l|l|l|l|l|}
\hline \multirow{2}{*}{ No. } & \multirow{2}{*}{ Indikator } & \multicolumn{5}{|l|}{ Jawaban Responden } \\
\cline { 3 - 6 } & & Ya & \multicolumn{3}{l|}{ Tidak } \\
\cline { 3 - 6 } & & $\mathbf{f}$ & $\mathbf{\%}$ & $\mathbf{f}$ & $\mathbf{\%}$ \\
\hline 1. & Motivasi & 42 & 84 & 8 & 16 \\
2. & Intelektual & 43 & 86 & 7 & 14 \\
3. & Sarana dan Prasarana & 43 & 86 & 7 & 14 \\
& Permainan Kecil & 41 & 82 & 9 & 18 \\
& Kemampuan Guru & 44 & 88 & 6 & 12 \\
Rata-rata & $\mathbf{4 3}$ & $\mathbf{8 6}$ & $\mathbf{7}$ & $\mathbf{1 4}$ \\
\hline
\end{tabular}

Tabel 8 di atas menunjukkan penerapan permainan kecil dalam proses pembelajaran Penjas Orkes, diperoleh 43 orang (86\%) responden Ya bahwa penerapan permainan kecil baik diterapkan dalam proses pembelajaran, sedangkan 7 orang (14\%) responden menyatakan masih Tidak. Dari data ini dapat dikatakan bahwa pada umumnya siswa menyatakan bahwa penerapan permainan kecil baik digunakan dalam proses pembelajaran Penjas Orkes, karena akan dapat meningkatkan motivasi siswa, peningkatan intelektual atau pemahaman siswa, dapat disesuaikan dengan kondisi sarana dan prasarana yang ada, pelaksanaan dapat berjalan dengan baik dan juga ditunjang oleh kemampuan guru yang baik pula.

\section{Pembahasan}

Penelitian yang dilakukan untuk mengungkapkan bagaimana penerapan permainan kecil dalam proses pembelajaran Penjas Orkes di MTsN Model Gunung Pangilun Padang. Untuk mengungkapkan hal ini dilihat tanggapan siswa mengenai penerapan permainan kecil yang dilihat dari lima aspek yaitu motivasi, intelektual, sarana dan prasarana, permainan kecil dan kemampuan guru. Temuan penelitian ini adalah penerapan permainan kecil dalam proses pembelajaran Penjas berjalan dengan baik, dimana 43 orang $(86 \%)$ responden menyatakan Ya, dan hanya 7 orang $(14 \%)$ responden menyatakan Tidak. Temuan ini menunjukkan bahwa siswa memberikan penilai mengenai penerapan permainan kecil dalam proses pembelajaran Penjas Orkes berhasil dengan baik, sehingga permainan ini baik untuk digunakan dalam proses pembelajaran yang dilaksanakan di lapangan.

Permainan kecil merupakan salah satu cara untuk memudahkan pencapaian tujuan pendidikan dalam pembelajaran pendidikan jasmani, olahraga dan kesehatan. Hal ini dapat terlaksana jika permainan kecil ini mempunyai manfaatnya dan menjadi sebuah kegiatan yang menyenangkan bagi 
siswa, sehingga siswa tertarik untuk mengikutinya. Penerapan permainan kecil akan berdampak pada peningkatan motivasi dan intelektual siswa. Selain itu permainan kecil ini dapat disesuaikan dengan kondisi sarana/prasarana yang ada, permainan kecil dapat dilaksanakan dengan mudah, dan didukung pula oleh kemampuan guru untuk melaksanakannya.

Permainan kecil akan dapat meningkatkan motivasi siswa, terutama motivasi fisik. Motivasi fisik merupakan dorongan untuk bertindak atau berbuat yang berhubungan dengan fisik, sebagai contoh adalah keinginan untuk bergerak sebanyak mungkin. Melalui permainan kecil siswa lebih termotivasi untuk mengikuti kegiatan pembelajaran. Hal ini dirasakan oleh 42 orang (84\%) responden yang menyatakan permainan kecil dapat membuat mereka termotivasi untuk mengikuti kegiatan pembelajaran. Temuan ini juga diperkuat oleh pendapat Roosvelt dalam Soemitro (1992:3) bahwa "keinginan bermain bagi peserta didik itu ada hubungannya dengan naluri bergerak, naluri atau dorongan bergerak ini harus dipuaskan dengan hal-hal yang menggembirakan dan menarik yaitu bermain".

Selanjutnya, permainan kecil juga dapat meningkatkan intelektual siswa yang dirasakan oleh 43 orang $(86 \%)$ responden. Permainan kecil ini baik diterapkan karena dapat meningkatkan intelektual siswa. Permainan kecil perlu didukung oleh sarana dan prasarana, dalam hal ini permainan kecil dapat menyesuaikan dengan kondisi sarana dan prasarana yang tersedia. Hal ini dinyatakan oleh 43 orang $(86 \%)$ responden.

Permainan kecil agar dapat meningkatkan hasil yang baik perlu dilaksanakan dengan baik pula. Hasil penelitian menunjukkan pelaksanaan permainan kecil itu sendiri berjalan dengan baik dinyatakan oleh 41 orang $(82 \%)$ responden. Proses permainan kecil yang berjalan dengan lancar akan dapat meningkatkan dan memudahkan pencapaian tujuan dari penerapan permainan kecil. Selain itu kemampuan guru juga sangat menentukan agar penerapan permainan kecil dalam mencapai target yang diinginkan. Hasil penelitian menunjukkan bahwa kemampuan guru dalam penerapan permainan kecil dikaitkan baik yang dinyatakan oleh 44 orang (88\%) responden.

Berdasarkan uraian diatas penerapan permainan kecil akan dapat meningkatkan motivasi dan intelektual siswa. Selain itu dalam menerapkan permainan kecil dapat dengan mudah disesuaikan dengan ketersediaan sarana dan prasarana yang ada, permainan ini juga membuat siswa merasa senang untuk mengikutinya. Dapat dikatakan bahwa penerapan permainan kecil baik berdampak baik dan mudah dilaksanakan sehingga permainan kecil ini dapat diterapkan dalam proses pembelajaran Penjas Orkes.

\section{KESIMPULAN}

Dari hasil penelitian dan pembahasan yang telah dilakukan maka dapat disimpulkan penerapan permainan kecil dalam pembelajaran Penjas Orkes berjalan dengan baik yang dinyatakan oleh 43 orang $(86 \%)$ responden menyatakan Ya dan hanya 7 orang $(14 \%)$ responden yang menyatakan Tidak. Ini berarti siswa menilai dan menganggap penerapan permainan kecil berjalan dengan baik dan tepat digunakan untuk meningkatkan ketertarikan siswa dalam mengikuti proses pembelajaran Penjas Orkes. Penerapan permainan kecil ini dapat dilihat pada aspek intelektual, sarana dan prasarana, permainan kecil dan kemampuan guru.

Dengan permainan kecil yang diterapkan semakin baik dalam proses pembelajaran Penjas Orkes maka diharapkan dapat meningkatkan kualitas proses dan hasil dari pembelajaran Penjas Orkes tersebut. Hal ini didukung oleh pendapat Soemitro (1992:6) menyatakan permainan kecil sebagai salah satu rangkaian aktivitas fisik akan memiliki banyak manfaat, serta mempunyai fungsi yang baik terhadap perkembangan fisik dan psikis seseorang, diantaranya membina mental, membina fisik, dan membina sosial.

Guru-guru Penjas Orkes hendaknya memberikan permainan kecil dalam pelajaran pembelajaran, karena permainan kecil ini dapat meningkatkan ketertarikan siswa untuk mengikuti proses pembelajaran. Siswa hendaknya mengikuti permainan kecil ini dengan sebaik-baiknya agar 


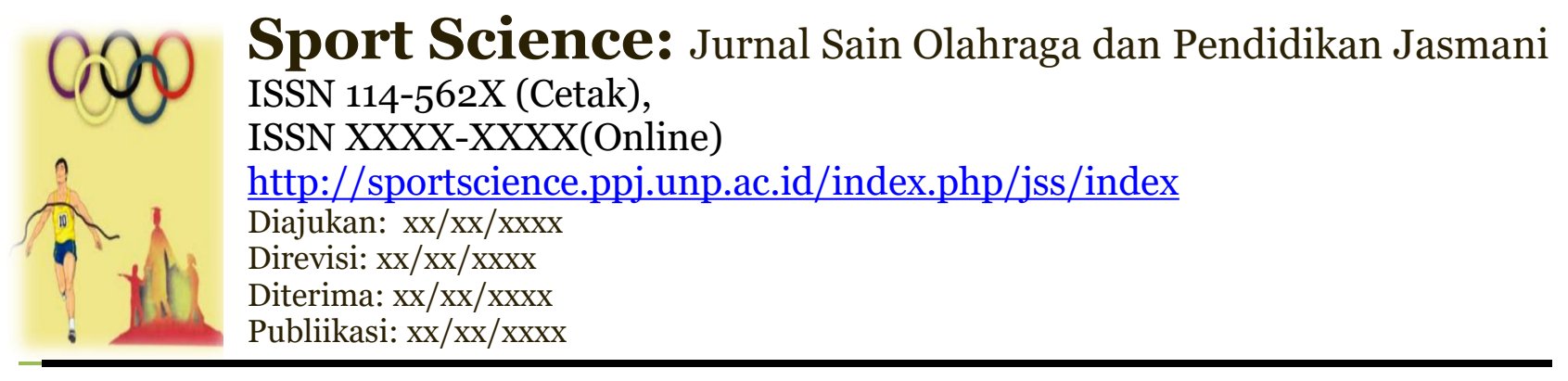

dapat meningkatkan kesehatan dan kondisi untuk fisik selalu baik, sehingga belajar yang diikuti akan terlaksana dengan baik.

Kepada sekolah supaya menyarankan guru-guru Penjas Orkes untuk melaksanakan permainan kecil dalam kegiatan proses belajar mengajar, karena dengan permainan kecil akan dapat meningkatkan motivasi untuk mengikutinya. Oleh karena penelitian ini masih berskala kecil, diharapkan peneliti lain melakukan penelitian pengembangan sehingga nantinya hasil dari penelitian tersebut memberi masukan bagi sekolah dan guru dan dunia pendidikan untuk menciptakan pembelajaran yang bermutu khususnya pembelajaran Penjas Orkes.

\section{DAFTAR RUJUKAN}

Arikunto, Suharsimi (2016). Prosedur Penelitian Suatu Pendekatan Praktik. Jakarta: PT. Rineka citra.

Asnaldi, A. (2015). Profesionalisme Guru Pendidikan Jasmani di Sekolah Dasar. Sport Science: Jurnal Ilmu Keolahragaan dan Pendidikan Jasmani, 23(28), 1-15.

Slamento. (1987). Belajar Dan Faktor-Faktor Yang Mempengruhi, Surabaya

Soemitro. (1992). Permainan Kecil. Depdikbud.

Sudjana. (1989). Metode Statistika. Bandung: Trasito. 